\title{
Oxysterol-Binding Protein-Related Protein
} 10

National Cancer Institute

\section{Source}

National Cancer Institute. Oxysterol-Binding Protein-Related Protein 10. NCI Thesaurus. Code C148556.

Oxysterol-binding protein-related protein 10 (764 aa, $~ 84 \mathrm{kDa})$ is encoded by the human OSBPL10 gene. This protein plays a role in subcellular phospholipid localization and cholesterol binding. 